\title{
As novas doenças da alma
}

\author{
Ivanise Fontes
}

Promessa cumprida. A Editora Rocco entrega aos leitores neste início de ano a esperada tradução em português de Les nouvelles maladies de l'ame, de Júlia Kristeva. Publicado originalmente na França pela Ed. Fayard, em 1993, esse, que é dos mais interessantes livros da autora, reúne uma coletânea de artigos e conferências.

Requisitada pelo meio psicanalítico francês e por inúmeros convites para reuniões européias de cunho político, esta psicanalista, lingüista, romancista e professora da Universidade Paris VII tem lugar de destaque no panorama cultural contemporâneo.

O presente livro se divide em duas partes: a clínica e a história. Podemos acompanhar desde seu início uma análise consistente das repercussões de nossos tempos modernos naquilo que chamamos vida psíquica. J. Kristeva se pergunta: “Quem, hoje em dia, ainda tem alma?” Instigante interrogação que nos remete à construção de nossa vida interior.

Habitante de um espaço e de um tempo fragmentados o homem moderno, segundo ela, mal reconhece sua fisionomia. Pressionado pelo estresse, impaciente por ganhar e gastar, por desfrutar e morrer, não tem tempo nem espaço necessários para construir uma alma. Tem um corpo que age, mas que 
desconhece que está submetido a uma redução espetacular de seu espaço psíquico. Espetáculo aqui é palavra-chave para essa constatação a que nos leva J. Kristeva de que a sociedade-show produz uma atrofia do psiquismo.

Em entrevista recente, J. Kristeva observava que a venda de livros na França continua em alta, o que não significa, de seu ponto de vista, que a leitura e a absorção de seus conteúdos se efetivem. Os franceses compram, mas se queixam nos divãs de não possuírem a concentração para o aproveitamento do que lêem. Um exemplo dentre outros da crescente dificuldade de simbolização.

Os doentes deste início de século fazem economia de suas vidas psíquicas. As novas nosografias, que incluem as falsas-personalidades, os estados psicossomáticos, as toxicomanias, as depressões, têm como denominador comum uma incapacidade de representação. Esses pacientes também denominados “modernos” empregam cada vez mais uma linguagem artificial, vazia, robotizada.

Nesse sentido, para a autora, boa parte de nosso mal contemporâneo origina-se de uma inibição do tempo sensível. Torna-se para ela vital resgatar a ligação do corpo à palavra porque não haveria despertar do sujeito enquanto uma significação de suas percepções e sensações não tivesse lugar.

Em sua análise crítica J. Kristeva não deixa de fora os analistas e se pergunta no título do segundo ensaio: "Para que servem os psicanalistas em tempo de desgraça que se ignora?” Acredita que duas confrontações aguardam a psicanálise do futuro: a primeira é a competição com a neurociência, e a segunda o desafio provocado à psicanálise pela aparente facilidade oferecida pela farmacologia.

Importante perceber então a defesa da autora de que a psicanálise de hoje e, sem dúvida a de amanhã, se volte mais atentamente para a pulsão: “Após seu período lingüístico, a psicanálise precisa decifrar a dramaturgia das pulsões para além da significação da linguagem em que se traveste o sentido pulsional. O analista deve considerar a polifonia para escutar o discurso que lhe é endereçado em diversos níveis - lingüístico e translingüístico (voz, gestos, etc...) e observar qual deles faz sentido na transferência”.

Por meio de relatos da análise de pacientes como a do "pulôver mortífero" - o texto é rico em exemplos clínicos - vemos a maestria clínica de J. Kristeva. Sua insistência sobre a sensorialidade e a utilização de uma palavra erotizada no trabalho analítico demonstram o reconhecimento de uma psicanálise que possa reabilitar o corpo sensível. O substrato energético das pulsões, a transferência entendida como reatualização dos traumas psicossensoriais anteriores são constituintes para ela de uma psicanálise que transpõe a fronteira corpo/alma.

$\mathrm{Na}$ segunda parte do livro, a "História”, encontramos ensaios sobre Literatura - James Joyce, Dostoievsky - e sobre arte - o belo artigo publicado no Le Nouvel Observateur de 1984 sobre o quadro de Leonardo da Vinci: A 
Virgem, Sant'Ana e o menino Jesus. E essa é a peculiaridade desta psicanalista que entrelaça num pensamento vivo outras dimensões da cultura.

Seus livros recentemente traduzidos são $O$ sentido e contra-senso da revolta (resenha de $O$ Globo de 26/2/2000) e $O$ feminino e o sagrado (em co-autoria com Catherine Clément), ambos também pela Rocco. Mas em sua produção incessante temos ainda uma trilogia por vir sobre "O gênio feminino" - três volumes com as mulheres escolhidas: a psicanalista inglesa Melanie Klein, a filósofa alemã Hanna Arendt e a escritora francesa Colette. Nova expectativa nos aguarda.

Linguagem clara e sensibilidade aguda são os atributos que encontramos em "Novas doenças da alma” e dos quais o texto psicanalítico se ressente nessas últimas décadas.

Vale a pena repetir suas palavras: “A psicanálise poderia ser um dos raros lugares, preservados, de mudança e surpresa, isto é: de vida.” 